\title{
PERTUMBUHAN DAN PRODUKTIVITAS KELOR (Moringa oleifera) PERIODE VEGETATIF AWAL DENGAN PEMUPUKAN SUMBER P YANG BERBEDA PADA TANAH ULTISOL
}

\author{
Simel Sowmen, Rusdimansyah, Siti Zainab dan Mari Santi \\ Program Studi Peternakan, Fakultas Peternakan Universitas Andalas \\ email: simel.hanna@gmail.com
}

\begin{abstract}
ABSTRAK
Penelitian rumah kaca dilakukan untuk mengetahui respon pertumbuhan kelor yang diberi sumber pupuk fospor yang berbeda pada tanah ultisol. Desain percobaan adalah rancangan acak lengkap (RAL) dengan 7 perlakuan pemupukan pospor yaitu o, $100 \mathrm{~kg} / \mathrm{ha} \mathrm{SP} 36,200 \mathrm{~kg} / \mathrm{ha} \mathrm{SP} 36,300 \mathrm{~kg} / \mathrm{ha} \mathrm{SP} 36,100 \mathrm{~kg} / \mathrm{ha} \mathrm{Rock}$ Phospat (RP), $200 \mathrm{~kg} / \mathrm{ha} \mathrm{RP}$, dan $300 \mathrm{~kg} / \mathrm{ha} \mathrm{RP}$, dengan 5 ulangan. Hasil penelitian menunjukkan bahwa pemupukan sumber $\mathrm{P}$ yang berbeda dengan berbagai level pemberian tidak berpengaruh nyata $(\mathrm{P}>0,05)$ terhadap pertumbuhan (tinggi tanaman, jumlah daun, jumlah ranting) dan produksi kelor (berat segar dan berat kering).
\end{abstract}

Kata kunci: kelor, Moringa oleifera, pertumbuhan, pupuk fospor

\begin{abstract}
Greenhouse study was conducted to investigate the effects of phosporous fertilizer on the growth and production of Moringa oleifera in ultisol. The experimental design was Completely Randomized Design (CRD), 7 treatments which include o kg/ha, $100 \mathrm{~kg} / \mathrm{ha} \mathrm{SP} 36,200 \mathrm{~kg} / \mathrm{ha} \mathrm{SP} 36,300 \mathrm{~kg} / \mathrm{ha} \mathrm{SP} 36,100 \mathrm{~kg} /$ ha Rock Phospat (RP), $200 \mathrm{~kg} / \mathrm{ha} \mathrm{RP}$, and $300 \mathrm{~kg} / \mathrm{ha} \mathrm{RP}$, in five replicates. The result showed there wasn't signicantly differences $(\mathrm{P}>0.05)$ of all phosporous fertilizer treatment to growth and production of moringa in early vegetative periode.
\end{abstract}

Keywords: plants growth, Moringa oleifera, phosporous fertilizer

\section{PENDAHULUAN}

Kelor (Moringa oleifera) merupakan tanaman herba dan pada umumnya dipergunakan sebagai sumber hijauan pakan bagi ternak ruminansia khususnya. Saat ini kelor dikenal sebagai miracle tree yang mempunyai banyak kegunaan bukan hanya sebagai tanaman pakan tetapi juga sebagai tanaman yang banyak khasiatnya dalam mengobati berbagai penyakit, bahkan juga dikenal sebagai tanaman pengusir setan. Sekarang kelor sangat sulit dijumpai karena belum dibudidayakan secara optimal, padahal dulu kelor ini sangat mudah dijumpai di perkampungan.

Saat ini penelitian tentang kelor banyak terfokus pada kualitas nutrisi dan nilai kesehatan yang diperoleh, sedangkan penelitian tentang budidaya kelor yang optimal masih sangat sedikit. Budidaya kelor saat ini gencar dikembangkan oleh peneliti di Zimbabwe (Gadzirayi et al, 2013), Kairo (Zayed, 2012), Pakistan (Anwar et al., 2006). Penelitian tentang teknik budidaya kelor yang optimal untuk mendapatkan produktivitas tinggi masih perlu dikembangkan di Indonesia.

Beberapa permasalahan dalam budidaya tanaman di Indonesia pada umumnya adalah kondisi tanah yang masam salah satunya ultisol. Ultisol tersebar cukup luas di Indonesia, yaitu sekitar 25\% dari luas daratan Indonesia (Subagyo et al., 2000). Pemanfaatan tanah ultisol untuk budidaya tanaman terkendala karena memiliki kesuburan yang rendah dan hal ini dapat menghambat pertumbuhan dan produksi tanaman. Rendahnya pertumbuhan dan produksi tanaman pada tanah ultisol ini disebabkan unsure hara $\mathrm{P}$ yang tidak tersedia bagi tanaman karena terikat oleh senyawa lain.

Salah satu alternative yang dapat dilakukan untuk mengatasi permasalahan di atas adalah dengan pemberian phosphor melalui pemupukan. Diharapkan pemberian pupuk sumber $P$ dapat membantu tanaman mendapatkan unsure $\mathrm{P}$ lebih banyak pada tanah ultisol. Pupuk sumber Phospor saat ini bisa dari SP36 yang bersifat cepat release, dan juga dari Rock Phospat yang lebih bersifat slow release.

Banyak penelitian tentang pemanfaatan Phospor d pada tanah ultisol dapat memperbaiki sifat kimia tanah dan pertumbuhan tanaman jagung (Rasyid, 2012; Haryanto et al., 2008), chickpea (Patil et al., 2011). Berdasarkan hal tersebut maka dilakukan 
penelitian tentang pengaruh pupuk sumber phosphor yang berbeda terhadap pertumbuhan kelor periode pertumbuhan vegetatif awal pada tanah ultisol.

\section{METODE PENELITIAN}

Materi yang digunakan pada penelitian ini adalah tanaman legume pakan Kelor (Moringa oleifera) yang didapatkan dari suplier bibit PT Lembah Hijau Kediri; pupuk kandang, pupuk Rock phospat danSP36, KCl, dan urea.

Penelitian ini dirancang menggunakan Rancangan Acak Lengkap (RAL) dengan 7 perlakuan, dan 5 ulangan. Perlakuan pemupukan $\mathrm{P}$ yang diberikan adalah P1: o kg/ha, P2: 10okg/ha SP36, $\mathrm{P}_{3}: 200 \mathrm{~kg} /$ ha SP36, P4: $300 \mathrm{~kg} / \mathrm{ha}, \mathrm{P}_{5}: 100 \mathrm{~kg} \mathrm{RP} / \mathrm{ha}, \mathrm{P} 6: 200$ $\mathrm{kg} / \mathrm{ha} \mathrm{RP}$, dan $\mathrm{P} 7: 300 \mathrm{~kg} / \mathrm{ha}$. Data yang diperoleh dianalisis dengan ANOVA, jika terdapat pengaruh terhadap peubah yang diukur maka dilanjutkan dengan uji LSMEAN.

\section{HASIL DAN PEMBAHASAN}

\section{Tinggi tanaman kelor}

Pemberian pupuk sumber $\mathrm{P}$ cenderung meningkatkan tinggi tanaman kelor setiap minggunya, walaupun secara statistik tidak berbeda nyata $(\mathrm{P}>0,05)$ dibandingkan dengan kontrol tanpa pemupukan $\mathrm{P}$ (P1) (Tabel 1). Hasil ini dimungkinkan oleh adanya pengaruh dari pupuk kandang yang diberikan pada seluruh perlakuan termasuk kontrol.

Tabel 1. Pengaruh pemupukan fospor terhadap tinggi tanaman kelor $(\mathrm{cm})$

\begin{tabular}{ccccc}
\hline \multirow{2}{*}{ Perlakuan } & \multicolumn{4}{c}{ Minggu } \\
\cline { 2 - 5 } & 1 & 3 & 5 & 7 \\
\hline P1 & 28.58 & 47.52 & 71.02 & 95.12 \\
P2 & 27.66 & 46.90 & 66.23 & 92.03 \\
P3 & 30.10 & 44.64 & 64.04 & 86.98 \\
P4 & 29.46 & 46.58 & 66.48 & 92.74 \\
P5 & 28.76 & 43.78 & 58.82 & 73.50 \\
P6 & 28.80 & 41.90 & 61.83 & 83.58 \\
P7 & 29.20 & 44.58 & 63.94 & 93.47 \\
\hline
\end{tabular}

\section{Jumlah daun per pot}

Analisis ragam menunjukkan bahwa perlakuan pemupukan phospor tidak berpengaruh nyata ( $>>0.05)$ terhadap jumlah daun kelor periode pertumbuhan vegetatif (Tabel 2).

\section{Jumlah ranting}

Tidak terlihat adanya pengaruh perlakuan pemupukan pospor $(\mathrm{P}>0.05)$ terhadap jumlah ranting tanaman kelor dari hasil analisis ragam (Tabel 3). Secara umum terlihat adanya kecenderungan peningkatan jumlah ranting kelor setiap minggu.
Tabel 2. Pengaruh pemupukan fospor terhadap jumlah daun kelor (helai)

\begin{tabular}{ccccc}
\hline \multirow{2}{*}{ Perlakuan } & \multicolumn{4}{c}{ Minggu } \\
\cline { 2 - 5 } & 1 & 3 & 5 & 7 \\
\hline P1 & 74.8 & 154.2 & 272.4 & 479.2 \\
P2 & 62 & 129.4 & 282 & 496.5 \\
P3 & 69.8 & 132.6 & 238 & 423.2 \\
P4 & 81.8 & 159.4 & 325 & 492.4 \\
P5 & 67 & 120.8 & 201.8 & 339.75 \\
P6 & 61 & 119.6 & 188.2 & 297.2 \\
P7 & 69.8 & 127.4 & 155.2 & 435.67 \\
\hline
\end{tabular}

Tabel 3. Pengaruh pemupukan fospor terhadap jumlah ranting kelor

\begin{tabular}{crrrr}
\hline \multirow{2}{*}{ Perlakuan } & \multicolumn{5}{c}{ Minggu } \\
\cline { 2 - 5 } & \multicolumn{1}{c}{ 1 } & \multicolumn{1}{c}{5} & \multicolumn{1}{c}{13} \\
\hline P1 & 9.6 & 13,6 & 25 & 13.25 \\
P2 & 8.4 & 12.2 & 15.5 & 17.25 \\
P3 & 9.4 & 13.2 & 15.8 & 15.2 \\
P4 & 9 & 13 & 16.4 & 16.8 \\
P5 & 9.2 & 13 & 15.8 & 18 \\
P6 & 8.4 & 11.8 & 14.25 & 16.5 \\
P7 & 9.2 & 13 & 16.6 & 19 \\
\hline
\end{tabular}

\section{Produksi Kelor Periode Vegetatif Awal}

Produksi kelor periode pertumbuhan vegetatif awal baik dalam berat segar maupun berat keringnya tidak dipengaruhi oleh pemupukan pospor dari hasil analisis ragam ( $\mathrm{P}>0.05)$ (Tabel 4).

Tabel 4. Pengaruh pemupukan fospor terhadap bobot kering kelor (g)

\begin{tabular}{ccccccc}
\hline \multirow{2}{*}{ Perlakuan } & \multicolumn{3}{c}{ Berat segar $(\mathrm{g})$} & \multicolumn{3}{c}{ Berat Kering $(\mathrm{g})$} \\
\cline { 2 - 7 } & Akar & Batang & Daun & Akar & Batang & Daun \\
\hline P1 & 7.00 & 14.00 & 14.67 & 0.88 & 2.56 & 1.82 \\
P2 & 9.67 & 15.00 & 17.00 & 1.88 & 3.27 & 3.59 \\
P3 & 6.00 & 13.00 & 14.00 & 1.02 & 2.76 & 2.34 \\
P4 & 7.33 & 15.67 & 15.67 & 0.90 & 3.14 & 4.16 \\
P5 & 6.67 & 8.67 & 11.00 & 0.69 & 1.96 & 1.28 \\
P6 & 5.33 & 10.67 & 11.67 & 0.67 & 2.15 & 2.45 \\
P7 & 6.00 & 12.00 & 16.00 & 0.83 & 2.53 & 4.13 \\
\hline
\end{tabular}

\section{KESIMPULAN}

Hasil penelitian menunjukkan bahwa pemberian pupuk sumber $\mathrm{P}$ (SP36 dan RP) tidak berpengaruh terhadap pertumbuhan dan produksi kelor periode vegetatif awal kemungkinan karena pada penelitian adanya kontribusi dari pupuk kandang pada kontrol. Saran untuk penelitian lanjutan adalah penelitian tanpa ada pemberian pupuk kandang sebagai pupuk dasar agar efektifitas pemupukan phospor yang diteliti lebih terlihat.

\section{UCAPAN TERIMA KASIH}

Terima kasih kepada Direktorat Jenderal Pendidikan Tinggi Kementerian Pendidikan dan Kebudayaan Nomor:030/SP2H/PL/DIT.LITABMAS/ 
II/2015. yang telah membantu pendanaan penelitian ini dalam skim Hibah Fundamental tahun anggaran 2015.

\section{DAFTAR PUSTAKA}

Anwar F, Hussain A.I., Ashraf M., Jamail A. and Iqbal S. 2006. Effect of salinity on yield and quality of Moringa oleifera seed oil. Grasas Y Aceites 57 (4):394-401

Gadzirayi C.T., Kubiku F.M.N., Mupangwa J.F., Mujuru L. and Chikuvire T.J. 2013. The Effect of Plant Spacing and Cutting Interval on Growth of Moringa Oleifera. Journal of Agricultural Science and Applications. 2(2):131-136

Haryanto, Idris K., Rafli I. Kawalusan dan Sisworo E.L. 2008. Pengaruh Pupuk Phospat Alam pada tanah masam terhadap pertumbuhan jagung serta serapan N-Za dan N-Urea. Jurnal Ilmiah Aplikasi Isotop dan Radiasi. Vol. 4 No. 2: 130-142.
Isaiah M.A. Effects of Inorganic Fertilizer on the Growth and Nutrient Composition of Moringa (Moringa oleifera). Journal of Emerging Trends in Engineering and Applied Sciences (JETEAS) 4(2): 341-343.

Patil S.V., Halikatti S.I., Hiremath S.M., Babalad H.B., Sreevina M.N., Hebsur N.S. dan Somanagoudag G. 2011. Effect of organic manures and rock phosphate on growth and yield of chickpea (Cicer arietinum L.) in vertisols. Karnataka J. Agric. Sci.,24 (5) : (636-638)

Rasyid B. 2012. Aplikasi kompos kombinasi zaeolit dan fosfat alam untuk peningkatan kualitas tanah ultisol dan produktivitas tanaman jagung. Jurnal Agrisistem. Vol. 8 No. 1: 13-22

Subagyo, H., N. Suharta dan A.B. Siswanto. 2004. Tanah-tanah Pertanian di Indonesia. Bogor : Pusat Penelitian Tanah dan Agroklimat: 21-66.

Zayed, M.S. 2012. Improvement of growth and nutritional quality of Moringa oleifera using different biofertilizers. Annals of Agricultural Science 57(1): 53-62 